\title{
Study on Innovative Research on Ideological and Political Education in Institutions of High Learning in the Era of "Internet Plus"
}

\author{
Lin Gui ${ }^{1, *}$ \\ ${ }^{1}$ School of Economics, Shandong Technology and Business University, Yantai, Shandong, 264005 \\ *Corresponding author.Email:291519686@qq.com
}

\begin{abstract}
The most significant feature in the era of mobile Internet is that a large amount of data can be used to realize information exchange and its accurate positioning. The rapid development of mobile Internet has exerted a certain influence on the ideological and political education of college students, as well as a certain impact on the concept and mode of traditional education, which are both an opportunity and a challenge to the ideological and political education for college students. This paper analyzes the challenges and opportunities faced by universities in ideological and political education in the "Internet plus" era from two aspects: challenges to the authority of discourse of ideological and political education and opportunities to its innovation in institutions of high learning brought by the rapid development of the "Internet +" era. According to the present situation, this paper provides theoretical support for the innovative research of ideological and political education in colleges and universities in the era of "Internet plus" by innovating its concept, expanding its content, diversifying its forms, strengthening its team construction and optimizing its information management system.
\end{abstract}

Keywords: "Internet plus", institutions of high learning, ideological and political education

\section{INTRODUCTION}

The reform and development of Internet technology is a profound revolution in the field of information technology industry, which has brought earth-shaking changes to our life. In the era of mobile Internet, the most significant feature is that a large amount of data can be used to enable people to realize information exchange regardless of time and place and its accurate positioning, which greatly meet people's requirements for things' convenience and initiative. The mobile Internet gives people the ability and vision to see the world as a whole. In the era of mobile Internet, people can make full use of massive data to analyze the personal preferences of the audience. In 2017, the General Offices of the CPC Central Committee and the State Council issued Guidelines on Promoting the Healthy and Orderly Development of the Mobile Internet, which is the China's first framework document on the development of the mobile Internet. The Guidelines point out that it should promote the innovative development of the mobile Internet, strengthen its driving and leading role, guard against its security risks and deepen its international exchanges and cooperation. It has high hopes for the development of mobile Internet. In the new era brought by the change of science and technology, the way of ideological and political education for college students should also change accordingly.
With the rapid development of Internet technology, ideological and political education in institutions of high learning is inevitably impacted and challenged by the Internet. At the same time, extensive Internet resources have brought great opportunities for its innovation and development. The pattern of education faced by institutions of high learning is undergoing profound changes. We should follow the trend and implant "Internet plus" thinking into various fields of ideological and political work to meet the diversified growth needs of students in an all-round way. How to make full use of the characteristics and advantages of the Internet in the course of ideological and political theory is a major subject faced by colleges and universities in their ideological and political education [1]. 


\section{CHALLENGES AND OPPORTUNITIES FACED BY INSTITUTIONS OF HIGH LEARNING IN IDEOLOGICAL AND POLITICAL EDUCATION IN THE ERA OF "INTERNET PLUS"}

\subsection{The challenge to the authority of the discourse of ideological and political education in institutions of high learning brought by rapid development of the "Internet plus" era}

The Internet is a virtual environment with complex channels and diversified values. What's more, it is a window for contemporary college students to understand and contact the society and the world. It has a profound influence on their value judgment and behavioral cognition. Under the current diversified social ideological trend, some people release distorting facts and confusing statements on the Internet under the guise of western democratic society. In addition, information publishers on the network are intermingled. They usually consider problems in a fragmented way. Therefore, it is easy to distort truth on the Internet. However, college students are in the critical period of constructing their world outlook, outlook on life and values, and they lack necessary life and social experience, so it is easy to shake the value belief and lose the direction of life. Ideological and political education in institutions of high learning is the main theoretical front for the dissemination of national mainstream ideology. The impact of the Internet makes students learn ideological and political theories in a fragmented way as well as greatly challenges the authority of ideological and political education discourse. With the advent of "Internet plus", quite a few colleges and universities fail to make full and effective use of this means and resources. As a result, the discourse power of ideological and political education is weakened in today's rapid development of information, which brings great challenges to mainstream ideological education.

\subsection{Opportunities to the innovation of ideological and political education in institutions of high learning brought by the rapid development of the "Internet +" era}

With the full coverage of the Internet and its integration into universities, "Internet plus" opens a new era of ideological and political education in institutions of high learning. The reform of mixed teaching has been carried out in many universities, which provides a new vision and opportunity for promoting the visualization of course teaching. On the one hand, "Internet plus" accelerates the timeliness and speed of people's access to information. Meanwhile, it also broadens the information channels for ideological and political education. A large number of excellent resources start to be integrated into all links of ideological and political education and teaching, providing rich resources and a broad platform for ideological and political education in colleges and universities. In teaching ideological and political course, teachers should fully and effectively integrate "Internet plus" into teaching, especially effectively use network media to form distinctive teaching methods and teaching contents, so as to ensure the continuous innovation and development of ideological and political course teaching. On the other hand, with the promotion and application of "Internet plus", the expression mechanism and channels of teachers and students are diversified, as well as the communication modes and means between teachers and students, which effectively alleviates the psychological pressure of students to communicate with teachers in class and is conducive to the construction of a new type of teacher-student relationship in the new era.

\section{NEW THOUGHT ON IDEOLOGICAL AND POLITICAL EDUCATION IN INSTITUTIONS OF HIGH LEARNING IN THE ERA OF "INTERNET PLUS"}

The "Internet plus" era is an era in which the Internet is deeply integrated with traditional industries. And it is a new environment that institutions of high learning must adapt to in their ideological and political education. In this new environment, facing new challenges and opportunities, colleges and universities should combine the characteristics of the "Internet plus" era to find new thought on ideological and political education to enhance its sense of the times and appeal [2]. The author believes that the following aspects should be observed.

\subsection{It should innovate the concept of ideological and political education in institutions of high learning}

Computers, mobile phones and all kinds of mobile terminal which rely on the Internet, have become the important tool for teachers and students in their daily communication, work and study. Thus, it can be seen that the Internet is constantly changing the soft environment of university and has changed the original role in which "teachers dominate the whole teaching process and students are passive learners". In order to adjust to the fundamental change of the role positioning in the relationship between teachers and students, colleges and universities should innovate their concepts on ideological and political education from the perspective of "Internet plus". Specifically speaking, we should develop the concept of "everything is for the development of students", which requires that faculties who focus their work on ideological and political education should attach great importance to the channels students obtain information and 
their ideological trend, take advantage of new media terminal, actively guide them to accept positive information, pay attention to their growth and development and focus on the all-round development. In addition, we should build the concept of open and equal interaction. Due to the Internet, college students have diversified channels to obtain ideological and political information. Faculties in institutions of high learning working on the ideological and political education should change their narrow-minded concept into an open-minded one, adjust to the change of educational mode from relatively stable one into an open and diversified one, transform narrow-minded ideological and political education into an open-minded one and combine theory with practice. Meanwhile, they should have such concept as combines equal interaction with guidelines, which requires them to observe the principle of "equality between teachers and students", promote the interaction between teachers and students and establish their own moral cognition and experience in the communicational process of interaction, mutual influence and mutual understanding [3]. In the process of ideological and political teaching, only by building new educational concept can we adjust to the new requirements on ideological and political education in institutions of high learning brought by the "Internet plus", thus realizing its goal.

\subsection{It should expand the content of ideological and political education in institutions of high learning}

The relation and exchange among countries are increasingly tight and the globalized trend is shown in the aspect of economy, culture, politics, etc. owe to the development of Internet, which means that under the background of "Internet plus", colleges and universities have a global "library" in their ideological and political education. Thus, it is inevitable to expand its content. Its basic content includes education on politics, ideology, moral, law and principles, psychology. In the process of expanding its content, it should take the textbook (basic content) as its core while guiding by policies to get to know the Internet culture popular among contemporary students, integrate it into ideological and political education and increase the content of moral education related to Internet which can be included into knowledge related to Internet moral regulations and law system. By doing so, we can strengthen college students' acknowledgement on ideological and political theories and make them have a firm faith on socialist core value. Furthermore, in its expanding process, we should center on innovative theories and education on major issues of CPC, increase the education on patriotism, honesty, outlook on world, life and value, employment, use scientific theories to arm college students' brain and strengthen their sensitivity and political discriminablity[4]. Eventually, the effect of ideological and political education in institutions of high learning can be improved and the requirements on ideological and political education to adjust to the development of Internet can be met.

\subsection{It should diversify the ways of ideological and political education}

The CPC Central Committee and the State Council have paid high attention to the current ideological and political education in institutions of high learning and issued Opinions of the CPC Central Committee and The State Council on Further Strengthening and Improving Ideological and Political Education among College Students to call for workers of ideological and political education to use more new media and new approaches to intensify their work under new situation [5]. Under such situation, to diversify the ways of ideological and political education has become the top priority of our work. In specific practice, we should analyze the characteristics of college students' ideology and behavior on the Internet and grasp the tendency of information spreading on the Internet and its evolvement principle [6], which requires us to build mainstream platform of new media. Thus, we should interact with college students and discuss social hot issues with them through colleges' forum, blog, WeChat, QQ, etc. in accordance with specific content of ideological and political education. For example, we can set up "Situation Room" or create a bunch of influential micro animations, movies and videos to strengthen the pertinence of the education and improve its appeal. In addition, we should improve classroom teaching. We should optimize the activities in and outside classroom by using Internet. In class, we should rely on the Internet and use micro-class and MOOC. At the meantime, we can build "College Students' Internet Culture Studio" and carry out distinctive activities related to ideological and political education, such as essay-writing, public speaking, learn-from-Lei Feng activities, social practice, activities related to selecting civilized class and clean dormitory according to its needs in order to cultivate their temperament and optimize their disposition and character in the extensive participation, thus achieving the best effect of ideological and political education [7].

\subsection{It should strengthen team construction of ideological and political education}

Institutions of higher learning, which perform the task of ideological and political education, have always been at the forefront of higher education. In the era of "Internet plus", it is very important to build a number of high-quality and professional teachers and management teams in ideological and political education. Therefore, in the process of building teachers' team in ideological and political education and counselor team and training professional teachers, students cadres and personnel of departments at all level, we should first of all provide 
technical training related to the Internet to make them proficiently master information technologies and good at using the latest software tools to conduct ideological and political teaching, thus achieving the perfect match between the Internet and ideological and political education. The specific way of training can be online course training. Teachers can register and $\log$ in the "Teacher Online learning Center" through IP authorization. After activating the course, students can study in any place. At the same time, it is also possible to organize a phased technical training on a semester basis, requiring relevant experts to give "face-to-face" training. Second, we can conduct an in-depth analysis of Mao Zedong theory, Deng Xiaoping Theory and Three Representatives and other important thoughts through special training, discussion and exchange and social practice organized by research group and endow them with new connotations in the Internet era, so that ideological and political educators can maintain their advanced thoughts [8].Therefore, it provides strong support and guarantee for carrying out ideological and political education from the perspective of "Internet plus".

\subsection{It should optimize information management system of ideological and political education in institutions of high learning}

In the era of "Internet plus", it can promote the coordinated advancement of ideological and political education in colleges and universities by optimizing the information management system of ideological and political education concerning mobile Internet for college students. Each work related to teaching management and service in colleges and universities have close relationship with information management, thus it cannot carry out the ideological and political education without information management under the background of "Internet plus". In view of this, under the unified leadership of the party committees of institutions of high learning, colleges and universities should mobilize and coordinate various forces to strengthen its information release and monitoring and the construction of problem-resolving mechanism on the mobile Internet, which means that we should build up the management and monitoring platform for data center application, unify identity recognition to collectively store and manage users' information, establish IP address management and user real-name registration system, and make workflow platform provide the management of process nodes and flow direction, etc. At the same time, we should construct public network storage system in colleges and universities to ensure teachers having sufficient ideological and political teaching and research resources and build the campus "cloud center". By doing so, we can form a perfect management mechanism, create an excellent educational environment for ideological and political education in colleges and universities under the background of "Internet plus", thus realizing the in-depth development of ideological and political education in colleges and universities.

\section{CONCLUSION}

With the development of China's economy and society and the improvement of people's living standards, people are more and more eager to pursue spiritual things, and social thoughts are becoming more and more diversified. Therefore, we are facing complex and severe challenges in ideological and political education for college students. Relying on mobile Internet technology, people can have a better understanding on students' ideological trends and needs, effectively improve its effectiveness and then impart and push notification of educational information, which is also an important direction for carrying out ideological and political education for college students in the future. The characteristic of "Internet plus" has injected new vitality into traditional ideological and political education in institutions of high learning and provided it with new methods, which is conducive to the continuous research and innovation of ideological and political education in colleges and universities. So, in face of opportunities and challenges brought by "Internet plus", colleges and universities should closely combine with the feature of the time, always adhere to the concept of student-oriented education, optimize and adjust each link of the ideological and political education and attach great importance to the summary of experience and refining. Only by doing so can we build the long-term mechanism of ideological and political education for college students characterized by "Internet plus" and better fulfill the fundamental task of training builders and successors of socialism with Chinese characteristics.

\section{REFERENCES}

[1] Gong Jianwei. Research on implicit Ideological and Political Education of College Students[D].Harbin: Northeast Forestry University,2017.

[2] Zhang Yongguang. Research on "Internet plus Ideological and Political Education" in the Army[D]. Changsha: National University of Defense Technology, 2016

[3] Xi Jinping. The Ideological and Political Works Through the Whole Process of Education and Teaching to Create a New Situation for the Development of China's Higher Education Cause [N]. People's Daily, 2016-12-09(1).

[4] Zhou Fuzhan, Mou Lin, On the Situation and Countermeasures of Network Ideology in Institutions of High Learning in the New Era[J]. Journal of Dalian University of Technology(Social Sciences), 2017, 38(4): 146-151. 
[5] Wang Xiaoxiao, Liu Hongfeng. An Analysis of Ideological and Political Education of College Students in the Era of "Internet Plus"[J]. Survey of Education, 2018, 7(7):16-17,23.

[6] Huang Xiaomei, Deng Haiqing, Wu Ying. Innovative Research on Ideological and Political Education of College Students in the Era of "Internet Plus"[J]. Journal of Hubei Correspondence University, 2017, 30(15):1-3.
[7] Lou Xiaomin. Ideological and Political Education for College Students in the Internet Era: Strategies and Suggestions [J]. China Educational Technology, 2016(6):136-139.

[8] Zhao Xiaoping. Innovative Research on the Effectiveness of College Students' Ideological and Political Education in the Era of mobile Internet [J].Review, 2014(4):58-61. 